\title{
GPR18, GPR55 and GPR119 (version 2019.4) in the IUPHAR/BPS Guide to Pharmacology Database
}

\author{
Stephen P.H. Alexander ${ }^{1}$ and Andrew J. Irving ${ }^{2}$
}

1. University of Nottingham, UK

2. University College Dublin, Ireland

\begin{abstract}
GPR18, GPR55 and GPR119 (provisional nomenclature), although showing little structural similarity to $\mathrm{CB}_{1}$ and $\mathrm{CB}_{2}$ cannabinoid receptors, respond to endogenous agents analogous to the endogenous cannabinoid ligands, as well as some natural/synthetic cannabinoid receptor ligands [98]. Although there are multiple reports to indicate that GPR18, GPR55 and GPR119 can be activated in vitro by N-arachidonoylglycine, lysophosphatidylinositol and N-oleoylethanolamide, respectively, there is a lack of evidence for activation by these lipid messengers in vivo. As such, therefore, these receptors retain their orphan status.
\end{abstract}

\section{Contents}

This is a citation summary for GPR18, GPR55 and GPR119 in the Guide to Pharmacology database (GtoPdb). It exists purely as an adjunct to the database to facilitate the recognition of citations to and from the database by citation analyzers. Readers will almost certainly want to visit the relevant sections of the database which are given here under database links.

GtoPdb is an expert-driven guide to pharmacological targets and the substances that act on them. GtoPdb is a reference work which is most usefully represented as an on-line database. As in any publication this work should be appropriately cited, and the papers it cites should also be recognized. This document provides a citation for the relevant parts of the database, and also provides a reference list for the research cited by those parts.

Please note that the database version for the citations given in GtoPdb are to the most recent preceding version in which the family or its subfamilies and targets were substantially changed. The links below are to the current version. If you need to consult the cited version, rather than the most recent version, please contact the GtoPdb curators.

\section{Database links}

GPR18, GPR55 and GPR119

http://www.guidetopharmacology.org/GRAC/FamilyDisplayForward?familyld=114

Receptors

GPR18

http://www.guidetopharmacology.org/GRAC/ObjectDisplayForward?objectld=89

GPR55 
http://www.guidetopharmacology.org/GRAC/ObjectDisplayForward?objectld=109

GPR119

http://www.guidetopharmacology.org/GRAC/ObjectDisplayForward?objectld=126

\section{References}

1. Agrawal A and Lynskey MT. (2009) Candidate genes for cannabis use disorders: findings, challenges and directions. Addiction 104: 518-32 [PMID:19335651]

2. Alexander SP. (2012) So what do we call GPR18 now?Br. J. Pharmacol. 165: 2411-3 [PMID:22014123]

3. Ali S, Lamont BJ, Charron MJ and Drucker DJ. (2011) Dual elimination of the glucagon and GLP-1 receptors in mice reveals plasticity in the incretin axis. J. Clin. Invest. 121: 1917-29 [PMID:21540554]

4. Anavi-Goffer S, Baillie G, Irving AJ, Gertsch J, Greig IR, Pertwee RG and Ross RA. (2012) Modulation of L- $\alpha$-lysophosphatidylinositol/GPR55 mitogen-activated protein kinase (MAPK) signaling by cannabinoids. J. Biol. Chem. 287: 91-104 [PMID:22027819]

5. Andradas C, Caffarel MM, Pérez-Gómez E, Salazar M, Lorente M, Velasco G, Guzmán M and Sánchez C. (2011) The orphan G protein-coupled receptor GPR55 promotes cancer cell proliferation via ERK. Oncogene 30: 245-52 [PMID:20818416]

6. Azimioara M, Alper P, Cow C, Mutnick D, Nikulin V, Lelais G, Mecom J, McNeill M, Michellys PY and Wang $Z$ et al.. (2014) Novel tricyclic pyrazolopyrimidines as potent and selective GPR119 agonists Bioorg. Med. Chem. Lett. 24: 5478-83 [PMID:25455488]

7. Bab I, Smoum R, Bradshaw H and Mechoulam R. (2011) Skeletal lipidomics: regulation of bone metabolism by fatty acid amide family. Br. J. Pharmacol. 163: 1441-6 [PMID:21557736]

8. Baker D, Pryce G, Davies WL and Hiley CR. (2006) In silico patent searching reveals a new cannabinoid receptor. Trends Pharmacol. Sci. 27: 1-4 [PMID:16318877]

9. Balenga NA, Aflaki E, Kargl J, Platzer W, Schröder R, Blättermann S, Kostenis E, Brown AJ, Heinemann A and Waldhoer M. (2011) GPR55 regulates cannabinoid 2 receptor-mediated responses in human neutrophils. Cell Res. 21: 1452-69 [PMID:21467997]

10. Bonini and James A. et al.. (2002) Methods of identifying compounds that bind to SNORF25 receptors. Patent number: US6468756.

11. Borrelli F and Izzo AA. (2009) Role of acylethanolamides in the gastrointestinal tract with special reference to food intake and energy balance. Best Pract. Res. Clin. Endocrinol. Metab. 23: 33-49 [PMID:19285259]

12. Bradshaw HB, Lee SH and McHugh D. (2009) Orphan endogenous lipids and orphan GPCRs: a good match. Prostaglandins Other Lipid Mediat. 89: 131-4 [PMID:19379823]

13. Breen C, Brownjohn PW and Ashton JC. (2012) The atypical cannabinoid O-1602 increases hind paw sensitisation in the chronic constriction injury model of neuropathic pain. Neurosci. Lett. 508: 119-22 [PMID:22227298]

14. Brown AJ. (2007) Novel cannabinoid receptors.Br. J. Pharmacol. 152: 567-75 [PMID:17906678]

15. Brown AJ, Daniels DA, Kassim M, Brown S, Haslam CP, Terrell VR, Brown J, Nichols PL, Staton PC and Wise A et al.. (2011) Pharmacology of GPR55 in yeast and identification of GSK494581A as a mixedactivity glycine transporter subtype 1 inhibitor and GPR55 agonist. J. Pharmacol. Exp. Ther. 337: 236-46 [PMID:21233197]

16. Brown AJ and Robin Hiley C. (2009) Is GPR55 an anandamide receptor?Vitam. Horm. 81: 111-37 [PMID:19647110]

17. Brown DG, Sanderson MR, Garman E and Neidle S. (1992) Crystal structure of a berenild(CGCAAATTTGCG) complex. An example of drug-DNA recognition based on sequence-dependent structural features. J. Mol. Biol. 226: 481-90 [PMID:1640462]

18. Burstein SH, McQuain CA, Ross AH, Salmonsen RA and Zurier RE. (2011) Resolution of inflammation by $\mathrm{N}$-arachidonoylglycine. J. Cell. Biochem. 112: 3227-33 [PMID:21732409]

19. Cantarella G, Scollo M, Lempereur L, Saccani-Jotti G, Basile F and Bernardini R. (2011) Endocannabinoids inhibit release of nerve growth factor by inflammation-activated mast cells. Biochem. Pharmacol. 82: 380-8 [PMID:21601562] 
20. Chiba T, Ueno S, Obara Y and Nakahata N. (2011) A synthetic cannabinoid, CP55940, inhibits lipopolysaccharide-induced cytokine mRNA expression in a cannabinoid receptor-independent mechanism in rat cerebellar granule cells. J. Pharm. Pharmacol. 63: 636-47 [PMID:21492165]

21. Chu ZL, Carroll C, Alfonso J, Gutierrez V, He H, Lucman A, Pedraza M, Mondala H, Gao H and Bagnol D et al.. (2008) A role for intestinal endocrine cell-expressed g protein-coupled receptor 119 in glycemic control by enhancing glucagon-like Peptide-1 and glucose-dependent insulinotropic Peptide release. Endocrinology 149: 2038-47 [PMID:18202141]

22. Chu ZL, Carroll C, Chen R, Alfonso J, Gutierrez V, He H, Lucman A, Xing C, Sebring K and Zhou $₫$ t al.. (2010) N-oleoyldopamine enhances glucose homeostasis through the activation of GPR119. Mol. Endocrinol. 24: 161-70 [PMID:19901198]

23. Chu ZL, Jones RM, He H, Carroll C, Gutierrez V, Lucman A, Moloney M, Gao H, Mondala H and Bagnol D et al.. (2007) A role for beta-cell-expressed $G$ protein-coupled receptor 119 in glycemic control by enhancing glucose-dependent insulin release. Endocrinology 148: 2601-9 [PMID:17289847]

24. Console-Bram L, Brailoiu E, Brailoiu GC, Sharir H and Abood ME. (2014) Activation of GPR18 by cannabinoid compounds: a tale of biased agonism. Br. J. Pharmacol. 171: 3908-17 [PMID:24762058]

25. Cox HM, Tough IR, Woolston AM, Zhang L, Nguyen AD, Sainsbury A and Herzog H. (2010) Peptide YY is critical for acylethanolamine receptor Gpr119-induced activation of gastrointestinal mucosal responses. Cell Metab. 11: 532-42 [PMID:20519124]

26. Daly CJ, Ross RA, Whyte J, Henstridge CM, Irving AJ and McGrath JC. (2010) Fluorescent ligand binding reveals heterogeneous distribution of adrenoceptors and 'cannabinoid-like' receptors in small arteries. $\mathrm{Br}$. J. Pharmacol. 159: 787-96 [PMID:20136833]

27. Davenport AP, Alexander SP, Sharman JL, Pawson AJ, Benson HE, Monaghan AE, Liew WC, Mpamhanga CP, Bonner TI and Neubig RR et al.. (2013) International Union of Basic and Clinical Pharmacology. LXXXVIII. G protein-coupled receptor list: recommendations for new pairings with cognate ligands. Pharmacol. Rev. 65: 967-86 [PMID:23686350]

28. Engelstoft MS, Egerod KL, Holst B and Schwartz TW. (2008) A gut feeling for obesity: 7TM sensors on enteroendocrine cells. Cell Metab. 8: 447-9 [PMID:19041758]

29. Fonseca BM, Teixeira NA, Almada M, Taylor AH, Konje JC and Correia-da-Silva G. (2011) Modulation of the novel cannabinoid receptor - GPR55 - during rat fetoplacental development. Placenta 32: 462-9 [PMID:21497900]

30. Ford LA, Roelofs AJ, Anavi-Goffer S, Mowat L, Simpson DG, Irving AJ, Rogers MJ, Rajnicek AM and Ross RA. (2010) A role for L-alpha-lysophosphatidylinositol and GPR55 in the modulation of migration, orientation and polarization of human breast cancer cells. Br. J. Pharmacol. 160: $762-71$ [PMID:20590578]

31. Fredriksson R, Höglund PJ, Gloriam DE, Lagerström MC and Schiöth HB. (2003) Seven evolutionarily conserved human rhodopsin G protein-coupled receptors lacking close relatives. FEBS Lett. 554: 381-8 [PMID:14623098]

32. Gantz I, Muraoka A, Yang YK, Samuelson LC, Zimmerman EM, Cook H and Yamada T. (1997) Cloning and chromosomal localization of a gene (GPR18) encoding a novel seven transmembrane receptor highly expressed in spleen and testis. Genomics 42: 462-6 [PMID:9205118]

33. Gao J, Tian L, Weng G, Bhagroo NV, Sorenson RL, O'Brien TD, Luo J and Guo Z. (2011) Stimulating beta cell replication and improving islet graft function by GPR119 agonists. Transpl. Int. 24: 1124-34 [PMID:21902730]

34. Gao J, Tian L, Weng G, O'Brien TD, Luo J and Guo Z. (2011) Stimulating $\beta$-cell replication and improving islet graft function by AR231453, A gpr119 agonist. Transplant. Proc. 43: 3217-20 [PMID:22099761]

35. Godlewski G, Offertáler L, Wagner JA and Kunos G. (2009) Receptors for acylethanolamides-GPR55 and GPR119. Prostaglandins Other Lipid Mediat. 89: 105-11 [PMID:19615459]

36. Han S, Narayanan S, Kim SH, Calderon I, Zhu X, Kawasaki A, Yue D, Lehmann J, Wong A and Buzard DJ et al.. (2015) Discovery of a novel trans-1,4-dioxycyclohexane GPR119 agonist series.Bioorg. Med.

Chem. Lett. 25: 3034-8 [PMID:26048791]

37. Hansen HS and Diep TA. (2009) N-acylethanolamines, anandamide and food intake.Biochem. Pharmacol. 
78: 553-60 [PMID:19413995]

38. Hansen HS, Rosenkilde MM, Holst JJ and Schwartz TW. (2012) GPR119 as a fat sensor.Trends Pharmacol. Sci. 33: 374-81 [PMID:22560300]

39. Hansen KB, Rosenkilde MM, Knop FK, Wellner N, Diep TA, Rehfeld JF, Andersen UB, Holst JJ and Hansen HS. (2011) 2-Oleoyl glycerol is a GPR119 agonist and signals GLP-1 release in humans. J. Clin. Endocrinol. Metab. 96: E1409-17 [PMID:21778222]

40. Henstridge CM, Balenga NA, Ford LA, Ross RA, Waldhoer M and Irving AJ. (2009) The GPR55 ligand Lalpha-lysophosphatidylinositol promotes RhoA-dependent Ca2+ signaling and NFAT activation. FASEB J. 23: 183-93 [PMID:18757503]

41. Henstridge CM, Balenga NA, Kargl J, Andradas C, Brown AJ, Irving A, Sanchez C and Waldhoer M. (2011) Minireview: recent developments in the physiology and pathology of the lysophosphatidylinositolsensitive receptor GPR55. Mol. Endocrinol. 25: 1835-48 [PMID:21964594]

42. Henstridge CM, Balenga NA, Schröder R, Kargl JK, Platzer W, Martini L, Arthur S, Penman J, Whistler JL, Kostenis E, Waldhoer M and Irving AJ. (2010) GPR55 ligands promote receptor coupling to multiple signalling pathways. Br. J. Pharmacol. 160: 604-14 [PMID:20136841]

43. Heynen-Genel S, Dahl R, Shi S, Milan L, Hariharan S, Sergienko E, Hedrick M, Dad S, Stonich D and Su $Y$ et al.. (2010) Screening for Selective Ligands for GPR55 - AntagonistsProbe Reports from the NIH Molecular Libraries Program [PMID:22091481]

44. Hiley CR and Kaup SS. (2007) GPR55 and the vascular receptors for cannabinoids.Br. J. Pharmacol. 152: 559-61 [PMID:17704825]

45. Ho WS. (2010) Angiogenesis: a new physiological role for N-arachidonoyl serine and GPR55?Br. J. Pharmacol. 160: 1580-2 [PMID:20649562]

46. Holst B, Nygaard R, Valentin-Hansen L, Bach A, Engelstoft MS, Petersen PS, Frimurer TM and Schwartz TW. (2010) A conserved aromatic lock for the tryptophan rotameric switch in TM-VI of seventransmembrane receptors. J. Biol. Chem. 285: 3973-85 [PMID:19920139]

47. Hu G, Ren G and Shi Y. (2011) The putative cannabinoid receptor GPR55 promotes cancer cell proliferation. Oncogene 30: 139-41 [PMID:21057532]

48. Huang L, Ramirez JC, Frampton GA, Golden LE, Quinn MA, Pae HY, Horvat D, Liang LJ and DeMorrow S. (2011) Anandamide exerts its antiproliferative actions on cholangiocarcinoma by activation of the GPR55 receptor. Lab. Invest. 91: 1007-17 [PMID:21464819]

49. Hughes TE. (2009) Emerging therapies for metabolic diseases--the focus is on diabetes and obesity.Curr Opin Chem Biol 13: $332-7$ [PMID:19482541]

50. Idris Al and Ralston SH. (2010) Cannabinoids and bone: friend or foe?Calcif. Tissue Int. 87: 285-97 [PMID:20532878]

51. Ishiguro $\mathrm{H}$, Onaivi ES, Horiuchi $\mathrm{Y}$, Imai $\mathrm{K}$, Komaki G, Ishikawa $\mathrm{T}$, Suzuki M, Watanabe $\mathrm{Y}$, Ando $\mathrm{T}$ and Higuchi S et al.. (2011) Functional polymorphism in the GPR55 gene is associated with anorexia nervosa. Synapse 65: 103-8 [PMID:20506567]

52. Izzo AA and Sharkey KA. (2010) Cannabinoids and the gut: new developments and emerging concepts. Pharmacol. Ther. 126: 21-38 [PMID:20117132]

53. John GW, Pauwels PJ, Perez M, Halazy S, Le Grand B, Verscheure Y, Valentin JP, Palmier C, Wurch T and Chopin $\mathrm{P}$ et al.. (1999) F 11356, a novel 5-hydroxytryptamine (5-HT) derivative with potent, selective, and unique high intrinsic activity at 5-HT1B/1D receptors in models relevant to migraine. J. Pharmacol. Exp. Ther. 290: 83-95 [PMID:10381763]

54. Johns DG, Behm DJ, Walker DJ, Ao Z, Shapland EM, Daniels DA, Riddick M, Dowell S, Staton PC, Green P, Shabon U, Bao W, Aiyar N, Yue TL, Brown AJ, Morrison AD and Douglas SA. (2007) The novel endocannabinoid receptor GPR55 is activated by atypical cannabinoids but does not mediate their vasodilator effects. Br. J. Pharmacol. 152: 825-31 [PMID:17704827]

55. Juknat A, Pietr M, Kozela E, Rimmerman N, Levy R, Coppola G, Geschwind D and Vogel Z. (2012) Differential transcriptional profiles mediated by exposure to the cannabinoids cannabidiol and $\Delta 9$ tetrahydrocannabinol in BV-2 microglial cells. Br. J. Pharmacol. 165: 2512-28 [PMID:21542829] 
56. Kapur A, Zhao P, Sharir H, Bai Y, Caron MG, Barak LS and Abood ME. (2009) Atypical responsiveness of the orphan receptor GPR55 to cannabinoid ligands. J. Biol. Chem. 284: 29817-27 [PMID:19723626]

57. Kargl J, Balenga NA, Platzer W, Martini L, Whistler JL and Waldhoer M. (2012) The GPCR-associated sorting protein 1 regulates ligand-induced down-regulation of GPR55. Br. J. Pharmacol. 165: 2611-9 [PMID:21718301]

58. Kargl J, Brown AJ, Andersen L, Dorn G, Schicho R, Waldhoer M and Heinemann A. (2013) A selective antagonist reveals a potential role of $G$ protein-coupled receptor 55 in platelet and endothelial cell function. J. Pharmacol. Exp. Ther. 346: 54-66 [PMID:23639801]

59. Katz LB, Gambale JJ, Rothenberg PL, Vanapalli SR, Vaccaro N, Xi L, Polidori DC, Vets E, Sarich TC and Stein PP. (2011) Pharmacokinetics, pharmacodynamics, safety, and tolerability of JNJ-38431055, a novel GPR119 receptor agonist and potential antidiabetes agent, in healthy male subjects. Clin. Pharmacol. Ther. 90: 685-92 [PMID:21975348]

60. Katz LB, Gambale JJ, Rothenberg PL, Vanapalli SR, Vaccaro N, Xi L, Sarich TC and Stein PP. (2012) Effects of JNJ-38431055, a novel GPR119 receptor agonist, in randomized, double-blind, placebocontrolled studies in subjects with type 2 diabetes. Diabetes Obes Metab 14: 709-16 [PMID:22340428]

61. Kinoshita M, Takahashi $Y$ and Arikawa K. (2012) Simultaneous brightness contrast of foraging Papilio butterflies. Proc. Biol. Sci. 279: 1911-8 [PMID:22179808]

62. Kogure R, Toyama K, Hiyamuta S, Kojima I and Takeda S. (2011) 5-Hydroxy-eicosapentaenoic acid is an endogenous GPR119 agonist and enhances glucose-dependent insulin secretion. Biochem. Biophys. Res. Commun. 416: 58-63 [PMID:22079287]

63. Kohno M, Hasegawa H, Inoue A, Muraoka M, Miyazaki T, Oka K and Yasukawa M. (2006) Identification of $\mathrm{N}$-arachidonylglycine as the endogenous ligand for orphan G-protein-coupled receptor GPR18. Biochem. Biophys. Res. Commun. 347: 827-32 [PMID:16844083]

64. Kotsikorou E, Lynch DL, Abood ME and Reggio PH. (2011) Lipid bilayer molecular dynamics study of lipidderived agonists of the putative cannabinoid receptor, GPR55. Chem. Phys. Lipids 164: 131-43 [PMID:21185816]

65. Kotsikorou E, Madrigal KE, Hurst DP, Sharir H, Lynch DL, Heynen-Genel S, Milan LB, Chung TD, Seltzman HH and Bai $Y$ et al.. (2011) Identification of the GPR55 agonist binding site using a novel set of high-potency GPR55 selective ligands. Biochemistry 50: 5633-47 [PMID:21534610]

66. Kreitzer FR and Stella N. (2009) The therapeutic potential of novel cannabinoid receptors Pharmacol. Ther. 122: 83-96 [PMID:19248809]

67. Kress M and Kuner R. (2009) Mode of action of cannabinoids on nociceptive nerve endings Exp Brain Res 196: 79-88 [PMID:19306092]

68. Lambert DM and Muccioli GG. (2007) Endocannabinoids and related N-acylethanolamines in the control of appetite and energy metabolism: emergence of new molecular players. Curr Opin Clin Nutr Metab Care 10: 735-44 [PMID:18089956]

69. Lan H, Lin HV, Wang CF, Wright MJ, Xu S, Kang L, Juhl K, Hedrick JA and Kowalski TJ. (2012) Agonists at GPR119 mediate secretion of GLP-1 from mouse enteroendocrine cells through glucose-independent pathways. Br. J. Pharmacol. 165: 2799-807 [PMID:22029751]

70. Lan H, Vassileva G, Corona A, Liu L, Baker H, Golovko A, Abbondanzo SJ, Hu W, Yang S and Ning Yet al.. (2009) GPR119 is required for physiological regulation of glucagon-like peptide-1 secretion but not for metabolic homeostasis. J. Endocrinol. 201: 219-30 [PMID:19282326]

71. Lauckner JE, Jensen JB, Chen HY, Lu HC, Hille B and Mackie K. (2008) GPR55 is a cannabinoid receptor that increases intracellular calcium and inhibits M current. Proc. Natl. Acad. Sci. U.S.A. 105: 2699-704 [PMID:18263732]

72. Lauffer L, lakoubov R and Brubaker PL. (2008) GPR119: "double-dipping" for better glycemic control. Endocrinology 149: 2035-7 [PMID:18427153]

73. Lauffer LM, lakoubov R and Brubaker PL. (2009) GPR119 is essential for oleoylethanolamide-induced glucagon-like peptide-1 secretion from the intestinal enteroendocrine L-cell. Diabetes 58: 1058-66 [PMID:19208912] 
74. Lin XH, Yuece B, Li YY, Feng YJ, Feng JY, Yu LY, Li K, Li YN and Storr M. (2011) A novel CB receptor GPR55 and its ligands are involved in regulation of gut movement in rodents. Neurogastroenterol. Motil. 23: 862-e342 [PMID:21726355]

75. Mascitti V, Stevens BD, Choi C, McClure KF, Guimarães CR, Farley KA, Munchhof MJ, Robinson RP, Futatsugi $\mathrm{K}$ and Lavergne SY et al.. (2011) Design and evaluation of a 2-(2,3,6-trifluorophenyl)acetamide derivative as an agonist of the GPR119 receptor. Bioorg. Med. Chem. Lett. 21: 1306-9 [PMID:21310611]

76. Matsumoto K, Yoshitomi T, Ishimoto Y, Tanaka N, Takahashi K, Watanabe A and Chiba K. (2018) DS8500a, an Orally Available G Protein-Coupled Receptor 119 Agonist, Upregulates Glucagon-Like Peptide1 and Enhances Glucose-Dependent Insulin Secretion and Improves Glucose Homeostasis in Type 2 Diabetic Rats. J. Pharmacol. Exp. Ther. 367: 509-517 [PMID:30217957]

77. McClure KF, Darout E, Guimarães CR, DeNinno MP, Mascitti V, Munchhof MJ, Robinson RP, Kohrt J, Harris AR and Moore DE et al.. (2011) Activation of the G-protein-coupled receptor 119: a conformationbased hypothesis for understanding agonist response. J. Med. Chem. 54: 1948-52 [PMID:21361292]

78. McHugh D. (2012) GPR18 in microglia: implications for the CNS and endocannabinoid system signalling. Br. J. Pharmacol. 167: 1575-82 [PMID:22563843]

79. McHugh D, Hu SS, Rimmerman N, Juknat A, Vogel Z, Walker JM and Bradshaw HB. (2010) Narachidonoyl glycine, an abundant endogenous lipid, potently drives directed cellular migration through GPR18, the putative abnormal cannabidiol receptor. BMC Neurosci 11: 44 [PMID:20346144]

80. McHugh D, Page J, Dunn E and Bradshaw HB. (2012) $\Delta(9)$-Tetrahydrocannabinol and N-arachidonyl glycine are full agonists at GPR18 receptors and induce migration in human endometrial HEC-1B cells. Br. J. Pharmacol. 165: 2414-24 [PMID:21595653]

81. McPartland JM, Glass M, Matias I, Norris RW and Kilpatrick CW. (2007) A shifted repertoire of endocannabinoid genes in the zebrafish (Danio rerio). Mol. Genet. Genomics 277: 555-70 [PMID:17256142]

82. McPartland JM, Matias I, Di Marzo V and Glass M. (2006) Evolutionary origins of the endocannabinoid system. Gene 370: 64-74 [PMID:16434153]

83. McPartland JM, Norris RW and Kilpatrick CW. (2007) Tempo and mode in the endocannaboinoid system. J. Mol. Evol. 65: 267-76 [PMID:17676365]

84. Moreno-Navarrete JM, Catalán V, Whyte L, Díaz-Arteaga A, Vázquez-Martínez R, Rotellar F, Guzmán R, Gómez-Ambrosi J, Pulido MR and Russell WR et al.. (2012) The L- $\alpha$-lysophosphatidylinositol/GPR55 system and its potential role in human obesity. Diabetes 61: 281-91 [PMID:22179809]

85. Naderi N, Majidi M, Mousavi Z, Khoramian Tusi S, Mansouri Z and Khodagholi F. (2012) The interaction between intrathecal administration of low doses of palmitoylethanolamide and AM251 in formalin-induced pain related behavior and spinal cord IL1- $\beta$ expression in rats. Neurochem. Res. 37: 778-85 [PMID:22201038]

86. Negoro K, Yonetoku Y, Maruyama T, Yoshida S, Takeuchi M and Ohta M. (2012) Synthesis and structureactivity relationship of 4-amino-2-phenylpyrimidine derivatives as a series of novel GPR119 agonists. Bioorg. Med. Chem. 20: 2369-75 [PMID:22365911]

87. Ning Y, O'Neill K, Lan H, Pang L, Shan LX, Hawes BE and Hedrick JA. (2008) Endogenous and synthetic agonists of GPR119 differ in signalling pathways and their effects on insulin secretion in MIN6c4 insulinoma cells. Br. J. Pharmacol. 155: 1056-65 [PMID:18724386]

88. No authors listed. (2010) Deal watch: Metabolex and Sanofi-Aventis partner on GPCR agonists for type 2 diabetes. Nat Rev Drug Discov 9: 670 [PMID:20811370]

89. Obara $Y$, Ueno S, Yanagihata $Y$ and Nakahata N. (2011) Lysophosphatidylinositol causes neurite retraction via GPR55, G13 and RhoA in PC12 cells. PLoS ONE 6: e24284 [PMID:21904624]

90. Oka S, Kimura S, Toshida T, Ota R, Yamashita A and Sugiura T. (2010) Lysophosphatidylinositol induces rapid phosphorylation of $\mathrm{p} 38$ mitogen-activated protein kinase and activating transcription factor 2 in HEK293 cells expressing GPR55 and IM-9 lymphoblastoid cells. J. Biochem. 147: 671-8 [PMID:20051382]

91. Oka S, Nakajima K, Yamashita A, Kishimoto S and Sugiura T. (2007) Identification of GPR55 as a Iysophosphatidylinositol receptor. Biochem. Biophys. Res. Commun. 362: 928-34 [PMID:17765871] 
92. Oka S, Toshida T, Maruyama K, Nakajima K, Yamashita A and Sugiura T. (2009) 2-Arachidonoyl-snglycero-3-phosphoinositol: a possible natural ligand for GPR55. J. Biochem. 145: 13-20 [PMID:18845565]

93. Okuno T and Yokomizo T. (2011) What is the natural ligand of GPR55?J. Biochem. 149: 495-7 [PMID:21324983]

94. Overton HA, Babbs AJ, Doel SM, Fyfe MC, Gardner LS, Griffin G, Jackson HC, Procter MJ, Rasamison $\mathrm{CM}$ and Tang-Christensen $\mathrm{M}$ et al.. (2006) Deorphanization of a $\mathrm{G}$ protein-coupled receptor for oleoylethanolamide and its use in the discovery of small-molecule hypophagic agents. Cell Metab. 3: 16775 [PMID:16517404]

95. Parker HE, Habib AM, Rogers GJ, Gribble FM and Reimann F. (2009) Nutrient-dependent secretion of glucose-dependent insulinotropic polypeptide from primary murine K cells. Diabetologia 52: 289-98 [PMID:19082577]

96. Pertwee RG. (2007) GPR55: a new member of the cannabinoid receptor clan?Br. J. Pharmacol. 152: 9846 [PMID:17876300]

97. Pertwee RG. (2010) Receptors and channels targeted by synthetic cannabinoid receptor agonists and antagonists. Curr. Med. Chem. 17: 1360-81 [PMID:20166927]

98. Pertwee RG, Howlett AC, Abood ME, Alexander SP, Di Marzo V, Elphick MR, Greasley PJ, Hansen HS, Kunos $G$ and Mackie K et al.. (2010) International Union of Basic and Clinical Pharmacology. LXXIX. Cannabinoid receptors and their ligands: beyond $\mathrm{CB}_{1}$ and $\mathrm{CB}_{2}$. Pharmacol. Rev. 62: 588-631 [PMID:21079038]

99. Petitet F, Donlan M and Michel A. (2006) GPR55 as a new cannabinoid receptor: still a long way to prove it. Chem Biol Drug Des 67: 252-3 [PMID:16611220]

100. Pietr M, Kozela E, Levy R, Rimmerman N, Lin YH, Stella N, Vogel Z and Juknat A. (2009) Differential changes in GPR55 during microglial cell activation. FEBS Lett. 583: 2071-6 [PMID:19464294]

101. Piñeiro R, Maffucci T and Falasca M. (2011) The putative cannabinoid receptor GPR55 defines a novel autocrine loop in cancer cell proliferation. Oncogene 30: 142-52 [PMID:20838378]

102. Qin Y, Verdegaal EM, Siderius M, Bebelman JP, Smit MJ, Leurs R, Willemze R, Tensen CP and Osanto S. (2011) Quantitative expression profiling of G-protein-coupled receptors (GPCRs) in metastatic melanoma: the constitutively active orphan GPCR GPR18 as novel drug target. Pigment Cell Melanoma Res 24: 20718 [PMID:20880198]

103. Romero-Zerbo SY, Rafacho A, Díaz-Arteaga A, Suárez J, Quesada I, Imbernon M, Ross RA, Dieguez C, Rodríguez de Fonseca F and Nogueiras $R$ et al.. (2011) A role for the putative cannabinoid receptor GPR55 in the islets of Langerhans. J. Endocrinol. 211: 177-85 [PMID:21885477]

104. Ross RA. (2009) The enigmatic pharmacology of GPR55.Trends Pharmacol. Sci. 30: 156-63 [PMID:19233486]

105. Ryberg E, Larsson N, Sjögren S, Hjorth S, Hermansson NO, Leonova J, Elebring T, Nilsson K, Drmota T and Greasley PJ. (2007) The orphan receptor GPR55 is a novel cannabinoid receptor. Br. J. Pharmacol. 152: 1092-101 [PMID:17876302]

106. Sakamoto Y, Inoue H, Kawakami S, Miyawaki K, Miyamoto T, Mizuta K and Itakura M. (2006) Expression and distribution of Gpr119 in the pancreatic islets of mice and rats: predominant localization in pancreatic polypeptide-secreting PP-cells. Biochem. Biophys. Res. Commun. 351: 474-80 [PMID:17070774]

107. Sawzdargo M, Nguyen T, Lee DK, Lynch KR, Cheng R, Heng HH, George SR and O'Dowd BF. (1999) Identification and cloning of three novel human G protein-coupled receptor genes GPR52, PsiGPR53 and GPR55: GPR55 is extensively expressed in human brain. Brain Res. Mol. Brain Res. 64: 193-8 [PMID:9931487]

108. Schuelert $\mathrm{N}$ and McDougall JJ. (2011) The abnormal cannabidiol analogue $0-1602$ reduces nociception in a rat model of acute arthritis via the putative cannabinoid receptor GPR55. Neurosci. Lett. 500: 72-6 [PMID:21683763]

109. Scott GA, Jacobs SE and Pentland AP. (2006) SPLA2-X stimulates cutaneous melanocyte dendricity and pigmentation through a lysophosphatidylcholine-dependent mechanism. J. Invest. Dermatol. 126: 855-61 [PMID:16456529] 
110. Scott JS, Birch AM, Brocklehurst KJ, Broo A, Brown HS, Butlin RJ, Clarke DS, Davidsson O, Ertan A and Goldberg K et al.. (2012) Use of small-molecule crystal structures to address solubility in a novel series of G protein coupled receptor 119 agonists: optimization of a lead and in vivo evaluation. J. Med. Chem. 55: 5361-79 [PMID:22545772]

111. Semple G, Fioravanti B, Pereira G, Calderon I, Uy J, Choi K, Xiong Y, Ren A, Morgan M and Dave Vet al.. (2008) Discovery of the first potent and orally efficacious agonist of the orphan G-protein coupled receptor 119. J. Med. Chem. 51: 5172-5 [PMID:18698756]

112. Semple G, Lehmann J, Wong A, Ren A, Bruce M, Shin YJ, Sage CR, Morgan M, Chen WC and Sebring K et al.. (2012) Discovery of a second generation agonist of the orphan G-protein coupled receptor GPR119 with an improved profile. Bioorg. Med. Chem. Lett. 22: 1750-5 [PMID:22264481]

113. Semple G, Ren A, Fioravanti B, Pereira G, Calderon I, Choi K, Xiong Y, Shin YJ, Gharbaoui T and Sage CR et al.. (2011) Discovery of fused bicyclic agonists of the orphan G-protein coupled receptor GPR119 with in vivo activity in rodent models of glucose control. Bioorg. Med. Chem. Lett. 21: 3134-41 [PMID:21444206]

114. Serrano A, Rivera P, Pavon FJ, Decara J, Suárez J, Rodriguez de Fonseca F and Parsons LH. (2012) Differential effects of single versus repeated alcohol withdrawal on the expression of endocannabinoid system-related genes in the rat amygdala. Alcohol. Clin. Exp. Res. 36: 984-94 [PMID:22141465]

115. Sharma R, Eng H, Walker GS, Barreiro G, Stepan AF, McClure KF, Wolford A, Bonin PD, Cornelius P and Kalgutkar AS. (2011) Oxidative metabolism of a quinoxaline derivative by xanthine oxidase in rodent plasma. Chem. Res. Toxicol. 24: 2207-16 [PMID:21939274]

116. Shore DM and Reggio PH. (2015) The therapeutic potential of orphan GPCRs, GPR35 and GPR55.Front Pharmacol 6: 69 [PMID:25926795]

117. Soga T, Ohishi T, Matsui T, Saito T, Matsumoto M, Takasaki J, Matsumoto S, Kamohara M, Hiyama H and Yoshida S et al.. (2005) Lysophosphatidylcholine enhances glucose-dependent insulin secretion via an orphan G-protein-coupled receptor. Biochem. Biophys. Res. Commun. 326: 744-51 [PMID:15607732]

118. Southern C, Cook JM, Neetoo-Isseljee Z, Taylor DL, Kettleborough CA, Merritt A, Bassoni DL, Raab WJ, Quinn E and Wehrman TS et al.. (2013) Screening $\beta$-Arrestin Recruitment for the Identification of Natural Ligands for Orphan G-Protein-Coupled Receptors. J Biomol Screen 18: 599-609 [PMID:23396314]

119. Staton PC, Hatcher JP, Walker DJ, Morrison AD, Shapland EM, Hughes JP, Chong E, Mander PK, Green PJ and Billinton A et al.. (2008) The putative cannabinoid receptor GPR55 plays a role in mechanical hyperalgesia associated with inflammatory and neuropathic pain. Pain 139: 225-36 [PMID:18502582]

120. Stone VM, Dhayal S, Smith DM, Lenaghan C, Brocklehurst KJ and Morgan NG. (2012) The cytoprotective effects of oleoylethanolamide in insulin-secreting cells do not require activation of GPR119. Br. J. Pharmacol. 165: 2758-70 [PMID:22029844]

121. Sumida H, Lu E, Chen H, Yang Q, Mackie K and Cyster JG. (2017) GPR55 regulates intraepithelial lymphocyte migration dynamics and susceptibility to intestinal damage. Sci Immuno/ 2: [PMID:29222090]

122. Szewczyk JW, Acton J, Adams AD, Chicchi G, Freeman S, Howard AD, Huang Y, Li C, Meinke PT and Mosely R et al.. (2011) Design of potent and selective GPR119 agonists for type II diabetes.Bioorg. Med. Chem. Lett. 21: 2665-9 [PMID:21273063]

123. Takenouchi R, Inoue K, Kambe $\mathrm{Y}$ and Miyata A. (2012) N-arachidonoyl glycine induces macrophage apoptosis via GPR18. Biochem. Biophys. Res. Commun. 418: 366-71 [PMID:22266325]

124. Thabuis C, Destaillats F, Landrier JF, Tissot-Favre D and Martin JC. (2010) Analysis of gene expression pattern reveals potential targets of dietary oleoylethanolamide in reducing body fat gain in $\mathrm{C} 3 \mathrm{H}$ mice. $\mathrm{J}$. Nutr. Biochem. 21: 922-8 [PMID:19954948]

125. Vassilatis DK, Hohmann JG, Zeng H, Li F, Ranchalis JE, Mortrud MT, Brown A, Rodriguez SS, Weller JR and Wright AC et al.. (2003) The G protein-coupled receptor repertoires of human and mouse.Proc. Natl. Acad. Sci. U.S.A. 100: 4903-8 [PMID:12679517]

126. Vezzulli L, Guzmán CA, Colwell RR and Pruzzo C. (2008) Dual role colonization factors connecting Vibrio cholerae's lifestyles in human and aquatic environments open new perspectives for combating infectious diseases. Curr. Opin. Biotechnol. 19: 254-9 [PMID:18501582] 
127. Waldeck-Weiermair M, Zoratti C, Osibow K, Balenga N, Goessnitzer E, Waldhoer M, Malli R and Graier WF. (2008) Integrin clustering enables anandamide-induced Ca2+ signaling in endothelial cells via GPR55 by protection against CB1-receptor-triggered repression. J. Cell. Sci. 121: 1704-17 [PMID:18445684]

128. Whalley NM, Pritchard LE, Smith DM and White A. (2011) Processing of proglucagon to GLP-1 in pancreatic $\alpha$-cells: is this a paracrine mechanism enabling GLP-1 to act on $\beta$-cells? J. Endocrinol. 211: 99106 [PMID:21795304]

129. Whyte LS, Ryberg E, Sims NA, Ridge SA, Mackie K, Greasley PJ, Ross RA and Rogers MJ. (2009) The putative cannabinoid receptor GPR55 affects osteoclast function in vitro and bone mass in vivo. Proc. Natl. Acad. Sci. U.S.A. 106: 16511-6 [PMID:19805329]

130. Wu Y, Kuntz JD, Carpenter AJ, Fang J, Sauls HR, Gomez DJ, Ammala C, Xu Y, Hart S and Tadepalli S. (2010) 2,5-Disubstituted pyridines as potent GPR119 agonists. Bioorg. Med. Chem. Lett. 20: 2577-81 [PMID:20227877]

131. Xia Y, Chackalamannil S, Greenlee WJ, Jayne C, Neustadt B, Stamford A, Vaccaro H, Xu XL, Baker H and O'Neill $\mathrm{K}$ et al.. (2011) Discovery of a nortropanol derivative as a potent and orally active GPR119 agonist for type 2 diabetes. Bioorg. Med. Chem. Lett. 21: 3290-6 [PMID:21536438]

132. Yamashita A, Kumazawa T, Koga H, Suzuki N, Oka S and Sugiura T. (2010) Generation of lysophosphatidylinositol by DDHD domain containing 1 (DDHD1): Possible involvement of phospholipase D/phosphatidic acid in the activation of DDHD1. Biochim. Biophys. Acta 1801: 711-20 [PMID:20359546]

133. Yamashita A, Oka S, Tanikawa T, Hayashi Y, Nemoto-Sasaki Y and Sugiura T. (2013) The actions and metabolism of lysophosphatidylinositol, an endogenous agonist for GPR55. Prostaglandins Other Lipid Mediat. 107: 103-16 [PMID:23714700]

134. Yin H, Chu A, Li W, Wang B, Shelton F, Otero F, Nguyen DG, Caldwell JS and Chen YA. (2009) Lipid G protein-coupled receptor ligand identification using beta-arrestin PathHunter assay. J Biol Chem 284: 12328-12338 [PMID:19286662]

135. Yoshida S, Ohishi T, Matsui T and Shibasaki M. (2010) Identification of a novel GPR119 agonist, AS1269574, with in vitro and in vivo glucose-stimulated insulin secretion. Biochem. Biophys. Res. Commun. 400: 437-41 [PMID:20804735]

136. Yoshida S, Ohishi T, Matsui T, Tanaka H, Oshima H, Yonetoku Y and Shibasaki M. (2011) The role of small molecule GPR119 agonist, AS1535907, in glucose-stimulated insulin secretion and pancreatic $\beta$-cell function. Diabetes Obes Metab 13: 34-41 [PMID:21114601]

137. Yoshida S, Ohishi T, Matsui T, Tanaka H, Oshima H, Yonetoku Y and Shibasaki M. (2010) Novel GPR119 agonist AS1535907 contributes to first-phase insulin secretion in rat perfused pancreas and diabetic $\mathrm{db} / \mathrm{db}$ mice. Biochem. Biophys. Res. Commun. 402: 280-5 [PMID:20937249]

138. Yoshida S, Tanaka H, Oshima H, Yamazaki T, Yonetoku Y, Ohishi T, Matsui T and Shibasaki M. (2010) AS1907417, a novel GPR119 agonist, as an insulinotropic and $\beta$-cell preservative agent for the treatment of type 2 diabetes. Biochem. Biophys. Res. Commun. 400: 745-51 [PMID:20816753]

139. Zhang X, Maor Y, Wang JF, Kunos G and Groopman JE. (2010) Endocannabinoid-like N-arachidonoyl serine is a novel pro-angiogenic mediator. Br. J. Pharmacol. 160: 1583-94 [PMID:20649563]

140. Zhu X, Huang D, Lan X, Tang C, Zhu Y, Han J, Huang W and Qian H. (2011) The first pharmacophore model for potent $G$ protein-coupled receptor 119 agonist. Eur J Med Chem 46: 2901-7 [PMID:21524831] 